\title{
Ethical challenges for doctors working in immigration detention
}

\section{Asylum seekers are not receiving acceptable standards of medical care. Should doctors boycott the system?}

\section{su}

he health of asylum seekers in Australia's immigration detention centres has been the subject of a doctors' letter of concern and two recent reports. ${ }^{1-3}$ Here, we present an analysis of the ethical dilemmas faced by health practitioners working in these centres ${ }^{1}$ and seek to promote a strong and considered policy discussion.

Australia's Department of Immigration and Border Protection (DIBP) contracts a private health service provider, International Health and Medical Services (IHMS), to provide health care to immigration centre detainees at an Australian standard. ${ }^{4}$ However, media and other reports from Christmas Island, ${ }^{1}$ Manus Island ${ }^{2}$ and $\mathrm{Nauru}^{3}$ have raised serious concerns about the quality of care provided and whether health care professionals have been able to fulfil their professional and ethical obligations to patients in these facilities. ${ }^{1-3}$

\section{Ethical conflicts and challenges}

Doctors working within the immigration detention system may experience conflicting loyalties to their patients, their employer and the DIBP. The Australian Health Practitioner Regulation Agency (AHPRA) code of conduct for doctors recognises the significance of conflicts of interest:

Multiple interests are common. They require identification, careful consideration, appropriate disclosure and accountability. When these interests compromise, or might reasonably be perceived by an independent observer to compromise, the doctor's primary duty to the patient, doctors must recognise and resolve this conflict in the best interests of the patient. ${ }^{5}$

The Australian Medical Association (AMA) code of ethics ${ }^{6}$ also advises how doctors should respond to conflicts of interest and to conditions that are judged to be unacceptable for adequate health care:

Refrain from entering into any contract with a colleague or organisation which may conflict with professional integrity, clinical independence or your primary obligation to the patient.

... ensure that you do not countenance, condone or participate in the practice of torture or other forms of cruel, inhuman, or degrading procedures ... 6

The AMA statement on medical professionalism ${ }^{7}$ further describes how a doctor's ability to deliver patient-centred care may be compromised by an employer or government and advises that:

\section{John-Paul Sanggaran* MBBS, MHMed, BHSC General Practitioner, and Conjoint Associate Lecturer ${ }^{l}$

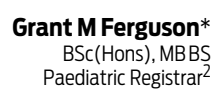 \\ Paediatric Registrar $^{2}$ \\ Bridget G Haire PhD, MBioethics Lecturer $^{1}$ \\ 1 School of Public Health and Community Medicine, University of New South Wales, Sydney, NSW. \\ 2 Department of Neonatology, Royal Women's Hospital, Melbourne, VIC \\ b.haire@unsw.edu.au \\ * Joint first authors} doi: 10.5694/mja14.01014

The potential role of a professional boycott to motivate change should be openly discussed

Online first 11/09/14
When responding to these challenges, the medical profession and its individual members have a duty to advocate that the health care environment remains patient-centred at all times and a responsibility to ensure that the health needs of patients remains the doctor's primary duty. ${ }^{7}$

Despite its obligations to both its patients and the DIBP, IHMS has publicly maintained that no conflict of interest exists. ${ }^{8}$ However, the inadequate health screenings of asylum seekers on Christmas Island in 2013 demonstrate this type of conflict. In response to DIBP targets, health assessments were rushed, fewer investigations were performed and asylum seekers were transferred to regional processing centres within 48 hours, before results of investigations were available. ${ }^{1}$ This resulted in failure to identify acute and chronic illnesses before patients were transferred to sites with limited medical facilities. ${ }^{1}$ This practice continued in the face of objections from the Royal Australasian College of Physicians. ${ }^{1}$

Some tasks requested of doctors in immigration detention centres are inappropriate in the context of health care, such as requests to refer patients for age assessment by the DIBP. This process is not a part of the patients' health care and is not in their best interests. ${ }^{1,9}$ Doctors have been required to prescribe medication en masse to expedite transfer to regional processing centres, with no patient consultation and despite potential contraindications. ${ }^{1}$ For example, the combination drug for malaria prophylaxis, atovaquoneproguanil hydrochloride, was prescribed without any individual patient consultation, and it was not clear if asylum seekers were informed about the indications for and possible adverse reactions to this drug.

Degrading, harmful and inappropriate incidents have occurred, including requiring asylum seekers to undergo health assessments while exhausted, dehydrated and filthy, with clothing soiled by urine and faeces; addressing individuals by number instead of name, ${ }^{1,2}$ artificial delays in transfer of patients for tertiary care, ${ }^{1}$ confiscation and destruction of medications, medical records and medical devices; 1 and detention of children despite clear evidence of significant harm. ${ }^{1,9-11}$

These rushed and inappropriate practices can have harmful consequences for patient wellbeing. These have included the loss of an unaccompanied child's hearing aid, which was not replaced, and the child went on to develop self-harming behaviour; and the abrupt cessation of anticonvulsants in a child, resulting in worsening of seizures. ${ }^{10,11}$ Tragically, delays in transfer are likely to have contributed to the recent death of an asylum seeker from sepsis, resulting from a cut to his foot. ${ }^{12}$ 


\section{Responding to conditions of practice in immigration detention centres}

Doctors who work in detention centres may feel an ethical responsibility to voice their concerns, but this may conflict with their obligations to their employer. The question should be asked: is working within immigration detention an ethically tenable prospect for Australian doctors and other health professionals? Several answers present themselves.

First, a doctor may advance the "no worse off" argument - that any individuals refusing to work within the system will be replaced by others willing to do so.

Second, it might be argued that it is better to have a compassionate person delivering the best care possible within the constraints of the detention system than to have that person leave, not knowing who the replacement will be. However, remaining silent goes against the imperative to advocate for patients' interests. ${ }^{7}$

Third, a doctor might work as contracted in the system, yet still advocate for asylum seekers by speaking out about deficiencies in their care. But it is unclear how much "advocacy from within" is enough. If that advocacy becomes ineffective, is there a point at which the doctor becomes effectively complicit with the system?

Finally, some doctors terminate their contracts when they see the realities of the detention health care environment. However, while this strategy preserves the individual's professional integrity, it may jeopardise patient care by resulting in an immediate workforce shortage.

The work culture in immigration detention centres discourages open expression of personal concerns by staff, with documented cases ending in dismissal. ${ }^{13}$ Formal complaints can be made but have rarely effected change. ${ }^{1}$ The diffusion of personal responsibility associated with reporting complaints to senior staff is a powerful factor in the immigration detention system. Health practitioners who lodge complaints to formalise their objections may judge this to have met their responsibilities. However, in reality, this may not represent effective advocacy for patients when failure to act on complaints is a systemic problem. Other doctors, increasingly frustrated with the lack of progress, may burn out and abandon their advocacy attempts. In our experience, many resolve to wait out their contracts and leave, never to return.

Appealing to bodies external to their employer becomes a last resort. However, individuals who do so face the possibility of legal action for breaching confidentiality agreements. Health care professionals can notify AHPRA, which provides protection from such agreements, but AHPRA's scope is limited to the conduct of individual practitioners rather than dysfunctional health systems as a whole. ${ }^{14}$ There is little else individuals can do without significant personal risk.

\section{Is it time for a boycott?}

Given reports that the health care currently provided to asylum seekers in immigration detention may be both substandard and harmful, a coordinated response to the problem is now needed to ensure change occurs.

Should health care professionals consider boycotting the provision of services in immigration detention until conditions are made satisfactory? The potential role of a professional boycott to motivate change should be openly discussed. Any decision made requires leadership from the professional bodies responsible for ensuring standards of care and ethical conduct. Any resulting policy and advice in relation to health care within immigration detention needs to be clear.

We call on the colleges and the AMA to lobby for effective change, so that asylum seekers receive appropriate care and those delivering it are not professionally compromised. We also call for robust, independent and transparent monitoring of standards within immigration detention, and a system to register and independently deal with complaints.

Competing interests: John-Paul Sanggaran and Grant Ferguson worked as medical officers at the Christmas Island Immigration Detention Centre during July-November 2013 and coauthored the doctors' letter of concern.

Provenance: Not commissioned; not externally peer reviewed.

1 Christmas Island doctors' letter of concern - in full. The Guardian 2014; Jan 13. http://www.theguardian. com/world/interactive/2014/jan/13/christmas-island-doctors-letter-of-concern-in-full (accessed Jun 2014).

2 This is breaking people: human rights violations at Australia's asylum seeker processing centre on Manus Island, Papua New Guinea. Sydney: Amnesty International Australia, Dec 2013. http://www.amnesty.org. au/images/uploads/about/Amnesty_International_Manus_Island_report.pdf (accessed Jun 2014).

3 Physical and Mental Health Subcommittee of the Joint Advisory Committee for Nauru Regional Processing Arrangements. Nauru site visit report: 16-19 February 2014. The Guardian 2014; May 30. http:// www.theguardian.com/world/interactive/2014/may/29/nauru-family-health-risks-report-in-full (accessed Jun 2014).

4 Joint Select Committee on Australia's Immigration Detention Network. Final report. Chapter 4 - Provision of health services to people in detention. Canberra: Commonwealth of Australia, 2012. http://www.aph. gov.au/Parliamentary_Business/Committees/Joint/Former_Committees/immigrationdetention/report/ c04 (accessed Jun 2014).

5 Medical Board of Australia. Good medical practice: a code of conduct for doctors in Australia. March 2014. http://www.ahpra.gov.au/News/2014-02-13-revised-guidelines-code-and-policy.aspx (accessed Jun 2014).

6 Australian Medical Association. AMA code of ethics - 2004. Editorially revised 2006. https://ama.com.au/ codeofethics (accessed Sep 2014).

7 Australian Medical Association. Medical professionalism - 2010. https://ama.com.au/positionstatement/medical-professionalism-2010 (accessed Jun 2014).

8 Marr D. Christmas Island: delays in medical transfers life-threatening, say doctors. The Guardian 2013; Dec 21. http://www.theguardian.com/world/2013/dec/21/christmas-island-delays-in-medical-transfers-lifethreatening-say-doctors (accessed Jun 2014).

9 Cotterill A, Andrews M, Ditchfield M, et al; Australasian Paediatric Endocrine Group, Royal Australasian College of Physicians, Australian and New Zealand Society for Paediatric Radiology, Royal Australian and New Zealand College of Radiologists. Assessment of age of refugees and those persons accused of providing refugees with illegal access to Australia: the unethical use of ionizing radiation ( $x$-rays) and/ or genital examination [letter to the Minister for immigration and Citizenship]. 19 Aug 2011. http://www. apeg.org.au/Portals/0/documents/o_age assessment letter to immigration minister.pdf (accessed Sep 2014).

10 Australian Human Rights Commission. National Inquiry into Children in Immigration Detention 2014 Transcripts from the inquiry's public hearings. https://www.humanrights.gov.au/our-work/asylumseekers-and-refugees/national-inquiry-children-immigration-detention-2014-1 (accessed Sep 2014).

11 Whyte S. Doctors gagged on mental ills of children in asylum centres. http://www.smh.com.au/federalpolitics/political-news/doctors-gagged-on-mental-ills-of-children-in-asylum-centres-20140731-3cx99. html (accessed Sep 2014).

12 Laughland O, Nissi D, Farrell P. Hamid Kehazaei dies after family give permission to switch off life support. The Guardian 2014; Sep 6. http://www.theguardian.com/world/2014/sep/05/hamid-kehazaeis-familygive-doctors-permission-to-switch-off-his-life-support (accessed Sep 2014).

13 Gordon M. Case worker sacked after calling Manus Island detention centre a hellhole. Sydney Morning Herald 2014; Jun 20. http://www.smh.com.au/federal-politics/political-news/case-worker-sacked-aftercalling-manus-island-detention-centre-a-hellhole-20140619-3ah2u.html (accessed Jul 2014).

14 Australian Health Practitioner Regulation Agency. Mandatory notifications. http://www.ahpra.gov.au/ Notifications/Who-can-make-a-notification/Mandatory-notifications.aspx (accessed Jun 2014). 